


\section{IAG ring test animal proteins 2018}


L.W.D. van Raamsdonk, B. Hedemann, C.P.A.F. Smits, J.J.M. Vliege, 2018. IAG ring test animal proteins 2018. Wageningen, RIKILT Wageningen University \& Research, RIKILT report 2018.008. 34 pp.; 2 fig.; 6 tab.; 16 ref.

Projectnummer: 128.736 .41 .01

Projecttitel: IAG ringtesten 2018

Projectleider: L.W.D. van Raamsdonk

This report can be downloaded for free at https://doi.org/10.18174/462578 or at www.wur.eu/rikilt (under RIKILT publications).

(C) 2018 RIKILT Wageningen University \& Research, institute within the legal entity Wageningen Research Foundation. Hereinafter referred to as RIKILT.

The client is allowed to publish or distribute the full report to third parties. Without prior written permission from RIKILT it is not allowed to:

a) publish parts of this report;

b) use this report or title of this report in conducting legal procedures, for advertising, acquisition or other commercial purposes;

c) use the name of RIKILT other than as the author of this report.

P.O. Box 230, 6700 AA Wageningen, The Netherlands, T +31 (0)317 4802 56, E info.RIKILT@wur.nl, www.wur.eu/rikilt. RIKILT is part of Wageningen University \& Research.

This report from RIKILT has been produced with the utmost care. However, RIKILT does not accept liability for any claims based on the contents of this report.

RIKILT report 2018.008

Distribution list:

- International Association for Feeding stuff Analysis (IAG), Section Feeding stuff Microscopy (G. Frick, R. Weiss, J. Vancutsem, R. Krull-Wöhrmann, I. Paradies-Severin)

- European Commission (EC; E. Thevenard, K. van Dijck, S. Perucho Martínez, F. Verstraete)

- European Union Reference Laboratory, Animal Proteins (CRA-W; G. Berben, P. Veys, V. Baeten)

- Joint Research Centre, Geel (IRMM-JRC; C. von Holst, A. Boix-Sanfeliu)

- All participants of the ring test

- European Fat Processing and Renderers Association (EFPRA; M. Alm, S. Woodgate)

- International Fishmeal and Fish oil Organisation (IFFO; A. Jackson, I. Pike)

- Ministry of Agriculture, Nature Management and Food Quality (LNV; E.L.J.M. Pierey, L.A.M. Claassen, A.D. Wentzel)

- Food and Consumer Product Safety Authority (VWA; K. Zwaagstra) 


\section{Contents}

$\begin{array}{ll}\text { Summary } & 5\end{array}$

1

$\begin{array}{ll}\text { Introduction } & 7\end{array}$

2

$\begin{array}{ll}\text { Methods } & 8\end{array}$

2.1 Materials $\quad 8$

2.2 Procedure for production $\quad 8$

2.3 Process control 9

2.4 Organization of the ring trial 9

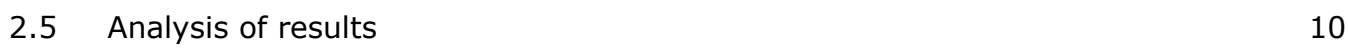

$3 \quad$ Results

3.1 Application of the method and reporting 11

3.2 Microscopic procedure 11

3.3 Microscopic detection $\quad 12$

3.4 Detection by PCR 13

4

$\begin{array}{ll}\text { Discussion } & 15\end{array}$

$\begin{array}{lll}4.1 & \text { Specificity and sensitivity } & 15\end{array}$

4.2 Application of the microscopic method 16

$\begin{array}{lll}4.3 & \text { PCR } & 17\end{array}$

$5 \quad$ Conclusions and recommendations $r$

$\begin{array}{lll}5.1 & \text { Conclusions } & 18\end{array}$

5.2 Recommendations $\quad 18$

$\begin{array}{lr}\text { Acknowledgements } & 19\end{array}$

$\begin{array}{ll}\text { References } & 20\end{array}$

$\begin{array}{lll}\text { Annex } 1 & \text { Introduction to the test } & 21\end{array}$

Annex 2 Basic instructions for the test procedure $\quad 22$

$\begin{array}{lll}\text { Annex } 3 & \text { Report form for procedure details } & 24\end{array}$

$\begin{array}{lll}\text { Annex } 4 & \text { Report form: results } & 25\end{array}$

$\begin{array}{lll}\text { Annex } 5 & \text { List of participants } & 26\end{array}$

Annex 6 Details of procedures applied, microscopic method 27

Annex 7 Results: presence of animal proteins, microscopic detection 29

Annex $8 \quad$ Results: reporting details and evaluation, microscopic detection $\mathbf{3 1}$

$\begin{array}{lll}\text { Annex } 9 & \text { Results: PCR ruminant } & 33\end{array}$ 



\section{Summary}

The annual ring test for the detection of animal proteins in animal feed of the IAG - International Association for Feeding stuff Analysis, Section Feeding stuff Microscopy was organized by RIKILT Wageningen UR, The Netherlands. The aim of the ring study was to provide the participants information on the performance of the local implementation of the detection methods for their local quality systems. A further aim was to gather information about the current practices in the application of the microscopic method. The current 2018 version of the IAG ring test for animal proteins facilitated the full analytical part of the methods for microscopy and PCR as published in Regulation (EC) 51/2013 amending Annex VI of Regulation (EC) 152/2009 together with accompanying SOPs. The four samples contain ruminant material at the legally required technical limit $(0.1 \% \mathrm{w} / \mathrm{w}$; Regulation (EC) $152 / 2009$ ), or fish meal at a spike level of $2 \%$ (w/w), or both. A fourth sample was left blank. The samples were based on a pig feed produced in a pilot plant, based on a commercial average composition. The feed contained $3 \%(\mathrm{w} / \mathrm{w})$ of bakery by-products. None of the samples was labelled as fish feed.

A total of 49 participants subscribed to the ring test animal proteins. Four participants did not submit their results. Of the remaining 45 participants, two applied exclusively PCR, leaving 43 sets of microscopic results, accompanied by PCR results in 20 cases.

\section{Microscopy}

All participants were requested to determine the presence or absence of land animal and/or fish, to indicate the type of material found and to describe the method used to achieve these results.

Ten participants (23.3\% of 43 participants)applied an incorrect number of determination cycles for one or more samples as required by the EU protocol. In total five participants $(12 \%)$ included incorrect interpretations of the encountered number of particles (e.g. "below threshold" for zero particles, "present" for 5 particles). In addition, two participants did not submit final conclusion on one or all samples. Therefore, all evaluations were based on the actual number of particles reported by all participants.

Incorrect positive results (positive deviations) were expressed in a specificity score and incorrect negative results (negative deviations) were expressed in a sensitivity score. An optimal score is 1.0. The results are analysed in two ways: numbers below threshold (between 1 and 5 particles per determination cycle inclusive) have been considered positive (complying to the zero tolerance) and as alternative considered as negative (for matching the official evaluation).

For all samples several participants did not detect terrestrial animal particles when present (sensitivity 0.95 and 1.0 in the presence or absence, respectively, of fish material) or erroneously reported terrestrial animal material when absent (specificity 0.84 and 0.91 in the presence or absence, respectively, of fish material).

The documentation for and training of microscopists for correct identification of particles of animal origin would deserve further attention in order to guard specificity. Evaluation of several aspects of the application of the current microscopic methods would be beneficial for improving harmonization among the laboratories applying the microscopic method.

\section{PCR}

Ruminant material was correctly detected in both samples containing $0.1 \%(\mathrm{w} / \mathrm{w})$ of terrestrial animal material in all 20 cases where PCR was applied. In the two samples without added terrestrial animal material, but still containing the bakery by-products, ruminant DNA was detected as far as analysed, except for one participant who reported negative. The list of recognised sources such as milk and milk products, and ruminant gelatine can be extended with bakery by-products, which is important for the recycling of food by-products. 


\section{Introduction}

The monitoring of the presence of animal proteins in feed for prevention of mad cow disease is an important part of the required active monitoring by member states of the European Union. With a long historical track record, microscopic detection of animal by-products is an important method for monitoring. The IAG - International Association for Feeding stuff Analysis, Section Feeding stuff Microscopy, serves as a platform for exchange of information, knowledge building and quality control. This international group organises annually a ring test for animal proteins in feeds for all their members. RIKILT - Wageningen UR organises this ring test on behalf of the IAG section Microscopy. Overviews of past results are presented in the annual reports of the ring tests for monitoring animal proteins in feed (latest version: van Raamsdonk et al., 2017a).

The current version of the microscopic method, together with an official method for DNA identification of ruminant material by means of PCR, was implemented by Regulation (EC) 51/2013 amending Annex VI of Regulation (EC) 152/2009: EC, 2013a, and its corrigendum EC, 2013b). The changes in the microscopic method implement a more detailed procedure, including details on slide preparation and a maximum of three determination cycles, each based on a new laboratory sample and a new sediment. The modifications were directed by the desire to gain in reproducibility and in harmonization (e.g. Veys et al., 2010). A Limit of Detection (LOD ${ }^{1}$ ) of five particles was set per determination cycle based on a laboratory sample of 10 grams. As of 1 June 2013 non-ruminant material is allowed as ingredient in aquafeed (Regulation (EC) 56/2013 amending Annex IV of Regulation (EC) 999/2001). Ruminant material remains prohibited, which needs a specified identification method, which was implemented by a PCR method. The combined application of the microscopic and PCR methods needs guidance, which is implemented in a Standard Operational Procedure (SOP) "operational schemes v3.0", developed by European Union Reference Laboratory (EURL). Other SOPs supporting the new method include details of the microscopic and PCR procedures, slide preparation among them.

As for every other qualitative detection method, sensitivity (frequency of false negatives) and specificity (frequency of false positives) are important indicators for the performance of the method. Although specific elements of a method can be installed for improving one these two indicators, there is a statistical relationship. In statistical terms, a decrease of a type I error (false positives) would imply an increase of a type II error (false negatives) or vice versa (Lindenmayer \& Burgman, 2005). An important issue is the correct and precise discrimination between terrestrial animal material and fish material, which are currently the major categories for monitoring. Confusion among particles of these two categories (see van Raamsdonk et al., 2017b), or with plant material or minerals will contribute to specificity and sensitivity scores lower than one.

The current 2018 version of the IAG ring test for animal proteins includes four samples with basic spike levels. The samples contain ruminant material at the legally required technical limit $(0.1 \% \mathrm{w} / \mathrm{w}$; Regulation (EC) 152/2009), or fish meal at a spike level of $2 \%(w / w)$, or both. A fourth sample was left blank. The final intention is, as in previous years, to provide the participants data on the performance of their own way of implementation, and to document the application of the two enforcement methods.

In this report the ring test for animal proteins 2018 is presented.

\footnotetext{
1 The term Limit of Detection suggests that findings below that level (here: 5 particles) are unreliable or even cannot be achieved properly. Instead, the issues of the presence of individual particles at low levels after microscopic examination might be related to possible lab contamination or to erroneous identification (specificity). Since the term LOD is originally defined in the framework of chemical analysis related to technical limitations instead of solving contamination or specificity issues, the term "threshold" is used here in the report.
} 


\section{Methods}

\section{$2.1 \quad$ Materials}

The IAG ring test for animal proteins 2018 was based on a pig feed, produced in 2003 in the framework of the European Union project STRATFEED and based on a regular composition of pig feed. The composition consisted of tapioca $(40 \%)$, soybeanmeal $(15.9 \%)$, rapeseedmeal $(12 \%)$, wheatglutenfeed (10.0\%) and wheat bran (2\%), palmkernelmeal (6\%), beetpulp (4\%), bakery byproducts $(3 \%)$, molasse $(2 \%)$, vegetable fat $(1.8 \%)$, barley $(1 \%)$, animal fat $(1.0 \%)$, limestone $(0.6 \%)$, lysine $(0.3 \%)$, salt $(0.2 \%)$ and vitamin/mineral mix $(0.2 \%)$.

The IAG ring test for animal proteins 2018 was combined with the IAG ring test for botanic composition (sample 2018-A).

The design of the ring test animal proteins allowed to apply the full analytical part of the method for the detection of animal proteins as published in Regulation (EC) 51/2013 amending Annex VI of Regulation (EC) 152/2009 (EC, 2013a), its corrigendum (EC, 2013b) and the accompanying SOPs. The samples were chosen to be fit for detection by both microscopy and PCR. None of the samples was indicated as feed for aquaculture. The choice and order of the methods was part of the study. The composition of the four samples is listed in Table 1.

Table 1 Composition of the samples in the NRL-IAG ring trial animal proteins 2018.

\begin{tabular}{lll} 
Label & Sample type & Content \\
\hline $2018-\mathrm{A}$ & pig feed & $2 \%(\mathrm{w} / \mathrm{w})$ fish meal \\
\hline $2018-\mathrm{B}$ & pig feed & Blank \\
\hline $2018-\mathrm{C}$ & pig feed & $0.1 \%(\mathrm{w} / \mathrm{w})$ ruminant MBM and $2 \%(\mathrm{w} / \mathrm{w})$ fish meal \\
\hline $2018-\mathrm{D}$ & pig feed & $0.1 \%(\mathrm{w} / \mathrm{w})$ ruminant MBM \\
\hline
\end{tabular}

The fish meal used for spiking were samples from practice, which were examined in the RIKILT regular control program and found to be negative for land animal material.

The ruminant meat and bone meal was collected from a Dutch trading company and identical to the material as used in the ring test in 2017.

\subsection{Procedure for production}

As in the ring test of 2017 (van Raamsdonk et al., 2017a), it was chosen to spike every jar individually. Based on a sample size of 50 grams, amounts of $50 \mathrm{mg}$ of meat and bone meal or $1000 \mathrm{mg}$ fishmeal, respectively, were individually weighted and stored in Eppendorf tubes. Each tube was labelled with the according number of the final jar. The material was added to every individual jar followed by homogenization. Every Eppendorf tube was stored for future reference. Although this procedure was identical to that of last year, an experiment was carried out to evaluate the efficiency and precision of the procedure. Ten times a tube was weighted, an amount of $50 \mathrm{mg}(49-51.5 \mathrm{mg})$ MBM was weighted and added to the tube, the filled tube was weighted, and finally the empty tube was weighted again. The tubes after emptying (average weight: $1.0067 \mathrm{~g} ; 1.0014-1.0153 \mathrm{~g}$ ) were on average $0.2 \mathrm{mg}$ heavier than before filling (average weight: $1.0065 \mathrm{~g} ; 1.0014-1.0153 \mathrm{~g}$ ). This results in a recovery of the procedure for weighting the PAP and filling the jars of $99.5 \%(98.8-100.0 \%)$. 


\subsection{Process control}

All basic materials were checked according to the procedure of Regulation (EC) 152/2009. Control of the presence of ruminant DNA by means of the EURL PCR method was performed on selected palm pit fragments and putative blood particles because of the report of blood material. The administration and physical evidence (numbered tubes) were stored for future reference (Figure 1).

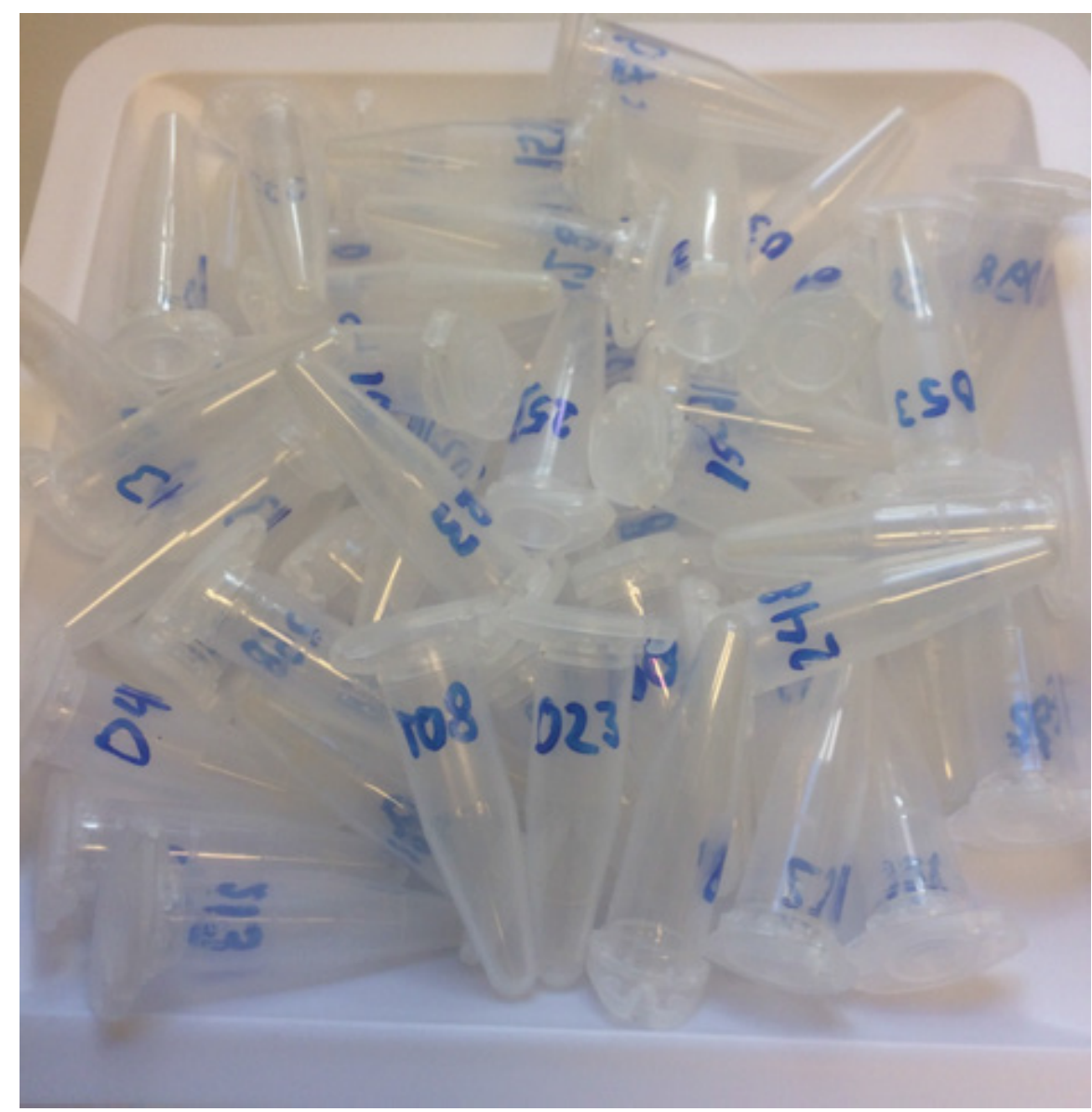

Figure 1 Empty tubes used for storing the PAP added to the individually numbered jars of sample C.

The microscopy research group and the PCR research group of RIKILT did not participate in the further laboratory analysis of this ring test.

\subsection{Organization of the ring trial}

All IAG members, all NRLs, participants of former ring tests and a series of putative interesting laboratories were informed about the ring test for 2018 by means of mailing using distribution lists. Until the beginning of March a total of 49 participants for the ring test animal proteins were listed. Participants outside Europe were informed to be aware of possible problems with custom regulations. The sets of four samples with an accompanying letter (see Annex 1) were sent to all participants on Monday $19^{\text {th }}$ of March 2018. All participants were informed the same day. On Monday April $2^{\text {nd }}$ an E-mail message was sent to all participants for supplying the file containing a sheet with instructions on reporting (see Annex 2) and the electronic report forms (see Annex 3 and 4).

The closing date for reporting results was originally fixed at Monday April $16^{\text {th }}$. Due to the late availability of the report form the final date postponed to Monday April $23^{\text {rd }}$. Notwithstanding this several requests were received to extent the period for analysis. Results received after the date at which the evaluation of the results was started were ignored. The analysis of the results was carried out between $8^{\text {th }}$ and $18^{\text {th }}$ of May. 
Since the new Regulation (EC) $152 / 2009$ as amended by Regulation (EC) $51 / 2013$ is fully operational for both microscopy and ruminant PCR, the reporting form was designed to accommodate both types of results. The report form consisted of four elements:

- Laboratory and sample numbers.

- Results of the microscopy analysis for up to three analyses. Depending on the results of this first determination the cells for the second determination were made active, and depending on the sum of first and second determination the cells for the third and last determination were made active. The final line consisted of a sum of particles found.

- Results of ruminant EURL-AP PCR method.

- The final conclusion of the participant.

The report form was interactive. The decision rule to make the set of cells active for the second determination was made as follows:

IF [\#terr.an. IS between 1-5] OR [\#fish IS between 1-5] THEN second determination

The decision rule for the third determination was based on the sum after two determinations. The text of the new method requires to perform an extra determination when the number of particles is between 1 and 5, which interpreted as directing a second (or third) analysis when ONLY one of the types of material was found to be within this range.

\subsection{Analysis of results}

As in every analytical method, several types of results exist, such as duplicate results, intermediate results and final results (conclusion). Since none of the samples was indicated as aquafeed, light microscopy is the only method for reaching the final conclusion, as stated in the SOP "Operational schemes v3.0". It is the intention of the ring test to establish primarily the analytical capability of the participants. Therefore, in those cases where the final conclusion as provided by a participant violates with the actual number of particles encountered, that number is used as basis for the evaluation.

The results are analysed in two ways: numbers below threshold (between 1 and 5 inclusive) have been considered positive and as alternative considered as negative. The choice to consider these number positive was based on the principle that any particle correctly identified as of animal origin is apparently present. This approach fits to the legal principle of zero tolerance and it allows a way to compare the present results with those of previous years.

For binary results (yes/no, positive/negative, etc.) standard statistics are accuracy, sensitivity and specificity. The accuracy is the fraction of correct results, either positive or negative. The sensitivity is the ability of the method used, to detect the contaminant when it is present, whereas the specificity is the ability to not detect the contaminant when it is absent. The following equations have been used to calculate the statistics:

$$
\begin{aligned}
& \text { Accuracy } A C=\frac{P A+N A}{P A+N D+P D+N A} \\
& \text { Sensitivity } S E=\frac{P A}{P A+N D} \\
& \text { Specificity } S P=\frac{N A}{P D+N A}
\end{aligned}
$$

where PA is the number of correct positive identifications (positive agreements), NA the number of correct negative identifications (negative agreements), PD the number of false positives (positive deviations) and ND the number of false negatives (negative deviations). The statistics are presented as fractions. Accuracy (specificity or sensitivity) has been calculated for each sample type. As criterion for a good or excellent score a threshold of 0.95 for either sensitivity or specificity was applied. 


\section{Results}

A total of 49 participants subscribed for the ring test animal proteins. Four participants did not submit their results. Of the remaining 45 participants, two applied exclusively PCR, leaving 43 sets of microscopic results, accompanied with PCR results in 20 cases. The participants originated from 19 countries: 13 member states of the European Union, and five other countries (China, Norway, Peru, Thailand and Switzerland). The list of participants is presented in Annex 5. Five member states have been involved with three or more participating laboratories: Germany (15 labs), Peru (4), the Netherlands (4), France (3), Belgium (3) and Spain (3).

All results were received by E-mail, in most cases by means of a scan and the original report file. Not in all cases a scan as pdf-file was submitted although clearly requested. In all those cases that a participant sent in several versions of the report sheet the most recent version was used. All full and correct reports were included. The draft report was finalised at May $28^{\text {th }}$. The full results are presented in the tables of Annex 6, 7 and 8.

\subsection{Application of the method and reporting}

Ten participants (23.3\% of 43 participants: $11,22,33,34,35,38,40,45,47,51)$ carried out an incorrect number of determination cycles for one or more samples. In nine of these ten cases more determination cycles were applied than requested by the official method. In total five participants $(12 \%: 3,33,35,40,47)$ included incorrect interpretations of the encountered number of particles (e.g. "presence" for zero particles, "absent" for one particle). In one of these occasions a result was adjusted based on the PCR results.

Incomplete or non-conclusive reports were submitted by a range of participants. The errors include missing results for one sample, a declaration of the same number for two different sample results, use of the unique number of another participant, a final conclusion without a declaration of a number of particles, and/or missing final conclusions for one or for all samples. Sixteen participants (37\% of 43 participants) were asked to clarify or complete their results. Participants were not contacted in all cases where the number of cycles and/or the number of declared particles could be evaluated without further information. If the second submitted version still contained any erroneous evaluation of their own results, this was accepted as such.

The official method includes basically several steps: the analytical procedure including the determination of the number of cycles, the drawing of the conclusion and filing the report. the latter part, the use of the official texts for reporting, is excluded from the procedure in this ring test (see Annex 2). An evaluation of the final conclusion as reported would combine the analytical and a part of "administrative" procedure. This evaluation would include the wrong interpretations of five participants and would be hampered by the missing conclusions of two other participants. Based on these issues, and in the view that the analytical performance of the participants should be the primary focus, the numbers of particles as reported are chosen as basis for the evaluation of the results. This approach also fits in the strategy to consider all results below the threshold as positive. As in previous years, the results with all results below threshold as negative will be shown as well.

\subsection{Microscopic procedure}

An inventory of nine different parameters was added to the report sheet of the actual results of the four samples. These results are shown in Annex 6 and summarised in Table 2. The main purpose of this inventory was to provide benchmark information for the individual participants for comparison with the general application of the method. Although this has to be considered additional information only, a ring test with a random set of participants provides a good opportunity to collect meta-data on the application of the method. The current results provide the opportunity to discuss some parameters of the microscopic method. 
The results as presented in Table 2 generally show a good application of the method, except for the number of determinations applied and for the embedding agent. Differences with previous years will be presented in the next chapter (Discussion).

The minimum share of the total amount of sediment declared to be used was 5\% (participants 20, 22 and 45). Several other participants used shares generally below $20 \%$. Most participants applied moderate portions, in some cases up to $100 \%$. Although this share indicates the represented portion of the original 10 grams, the absolute amount of sediment material collected after sedimentation is an additional factor for interpreting these percentages. The application of $12 \%$ from a sediment of $243 \mathrm{mg}, 16 \%$ of $200 \mathrm{mg}$ or $26 \%$ of $138 \mathrm{mg}$ for producing three slides, all result in an approximate use of $10 \mathrm{mg}$ sediment material per slide, as advised in the relevant SOP. Situations ranging from $5 \%$ of $176 \mathrm{mg}$ sediment material (2.7 mg per slide) to $79 \%$ of $324 \mathrm{mg}$ sediment material used ( $85 \mathrm{mg}$ per slide) were found among the submitted data of the participants. Besides the amount of material used for analyses, this high diversity of the amount of sediment material obtained would deserve further attention.

Table 2 Inventory of parameters for microscopic detection and their application. Pink cells indicate deviations from the official method. *: different types of glassware are in use, which could be summarised of glassware as "champagne glass". The correct indication needs further examination.

\begin{tabular}{|c|c|c|c|}
\hline Parameter & parameter state & $\begin{array}{l}\text { number of } \\
\text { participants }\end{array}$ & amount \\
\hline \multirow{2}{*}{$\begin{array}{l}\text { Correct application of the number of } \\
\text { determinations }\end{array}$} & yes & 33 & \\
\hline & no; insufficient determinations & 0 & \\
\hline Extra milling step $(<1.0 \mathrm{~mm})$ & no & 34 & \\
\hline \multirow[t]{4}{*}{ type of glassware } & chemical sedimentation funnel & 20 & \\
\hline & conical glass with cock & 6 & \\
\hline & champagne glass * & 8 & \\
\hline & beaker (flat bottom) & 5 & \\
\hline \multirow[t]{2}{*}{ use of staining of sediment } & no & 26 & \\
\hline & yes & 16 & \\
\hline \multirow{2}{*}{$\begin{array}{l}\text { use of binocular for examination at lower } \\
\text { magnifications }\end{array}$} & yes & 32 & \\
\hline & no & 10 & \\
\hline \multirow[t]{3}{*}{ size of cover glass used } & small (e.g. $20 \times 20 \mathrm{~mm}$ ) & 34 & \\
\hline & medium & 3 & \\
\hline & large (e.g. $26 \times 50 \mathrm{~mm}$ ) & 4 & \\
\hline \multirow{2}{*}{$\begin{array}{l}\text { share of the total sediment used for } \\
\text { examination }\end{array}$} & minimum & & $5 \%$ \\
\hline & maximum & & $100 \%$ \\
\hline
\end{tabular}

\subsection{Microscopic detection}

The results of the application of the microscopic detection, expressed exclusively on the basis of declared numbers of particles, are presented in Table 3; full results are listed in Annex 7. The amount of added material, $0.1 \%(\mathrm{w} / \mathrm{w})$ of terrestrial animal material and/or $2 \%(\mathrm{w} / \mathrm{w})$ of fish material, would theoretically be sufficient for the application of one determination cycle at all times to reach a 
conclusive result. Eighteen participants reported the maximum number of particles possible according the report form (16) after one cycle in all cases. An additional participant reported 15 particles after one cycle for one single sample combined with 16 particles in all other cases. Ten participants reported average numbers of particles below 16 but well over the threshold of 5 particles per cycle for all samples. It can be noted that the participants reporting less than the maximum number possible in the report form (16) primarily report this lower number for terrestrial animal material in the presence of fish meal. This is the category $B$ in the overview in Annex 8. The remaining 15 participants declared one or more errors.

The total overview of results shows suboptimal values for both specificity and sensitivity situations. Four participants $(22,34,43,47)$ and three participants $(43,46,51)$, respectively, reported particles of terrestrial animals or fish material in the blank sample 2018-B. Up to 44 particles in this blank were declared by one participant. In one case blood particles were declared for samples $A$ and $B$, which did not contain added material of terrestrial animal material. Participants 28 and 35 did not detect the terrestrial animal material in sample C (sample numbers 108 and 23, respectively). These specific samples have been spiked in the normal procedure along with all other jars of sample $\mathrm{C}$. The emptied tubes are shown in Figure 1.

Table 3 Sensitivity and specificity scores for the detection of animal proteins by the microscopic method of four samples (top row: values below the threshold considered positive; bottom row in italics: values below the threshold considered negative). Abbreviations: n: number of participants. Capitals A to D: sample indication.

\begin{tabular}{|c|c|c|c|c|c|c|c|c|c|}
\hline & & \multicolumn{4}{|c|}{ Terrestrial animal } & \multicolumn{4}{|l|}{ Fish } \\
\hline & & A & B & C & $D$ & A & $\mathbf{B}$ & C & $D$ \\
\hline \multicolumn{2}{|l|}{$n$} & $0 \%$ & $0 \%$ & $0.1 \%$ & $0.1 \%$ & $2 \%$ & $0 \%$ & $2 \%$ & $0 \%$ \\
\hline \multirow{2}{*}{43} & & 0.95 & 0.95 & & & & 0.98 & & 1.0 \\
\hline & sensitivity & & & 0.95 & 1.0 & 1.0 & & 1.0 & \\
\hline
\end{tabular}

The results were stratified according to several of the parameters as presented in Table 2. No significant differences were found among the different states for each of these parameters.

\subsection{Detection by PCR}

Participants were invited to perform DNA analysis targeted for ruminants (EURL-AP Method) and to submit their results together with the results for microscopy. Although none of the feeds was indicated as feed for aquaculture, twenty participants reported results for the two samples (C and D) which were found positive after microscopic analysis. Eleven of them also reported results for one or both of the samples $A$ and $B$. The overall results are almost perfect (Table 4). Full results are shown in Annex 8. Although participant 3 submitted the results of three different technicians (see Annex 8), this participants was counted as one set of results for the evaluation.

Table 4 Results for DNA analyses (PCR) for four samples. Target: ruminant. *: results based on the presence of $3 \%$ bakery by-products in the matrix.

\begin{tabular}{llllll} 
& Ruminant & & & \\
& A & B & C & D \\
& & $0 \% *$ & $0 \% *$ & $0.1 \%$ & $0.1 \%$ \\
\hline specificity & & & & \\
\hline sensitivity & 0.90 & 0.89 & 1.0 & 1.0 \\
\hline $\mathrm{n}$ & 10 & 9 & 20 & 20 \\
\hline
\end{tabular}


For a further analysis all participants were asked to provide their Ct values and cut-off value. This appeared necessary for a proper evaluation of the detection of the bakery-by-products. As far as received the details are shown in Annex 8. One participant (23) apparently adjusted their implementation of the PCR method in such a way that the ruminant material at $0.1 \%(\mathrm{w} / \mathrm{w})$ was properly detected, whereas the addition of $3 \%$ of bakery by-products in the pig feed resulted in a signal later than their cut-off value. All participants achieved earlier signals for the ruminant material compared to the signals resulting from the bakery by-products, as is illustrated by a colour shading in Annex 8. Participant 52 applied their own methods for ruminant as well as for other animals. They found positive signals for pig and poultry in some of the samples as well.

Selected material of palm pit and of presumed blood particles were investigated for the presence of eukaryotic DNA and of ruminant DNA. In both types of material a limited amount of DNA appeared to be present, and no ruminant signal was found. 


\section{Discussion}

\subsection{Specificity and sensitivity}

The design of the current version of the IAG ring test for animal proteins was intended to be relatively straightforward. It was based on an almost identical composition of samples as at the start of the RIKILT organisation (van Raamsdonk et al., 2009): $0.1 \%(w / w)$ of terrestrial animal material (ruminant) and $5 \%(\mathrm{w} / \mathrm{w})$ of fish material in every combination. The level of detection of the microscopic method is much lower than 0.1\% (Engling et al., 2000; Veys et al., 2010; van Raamsdonk et al., 2014) and the hypothesis was that a vast majority of participants would be able to report the maximum number of particles accepted in the report form (16 particles per type per cycle). Accepting 15 particles as close to the optimal score, 19 participants were able to report this for all relevant samples, which is $44 \%$ of all participants. At the other end of the spectrum, twelve participants (28\%) account for all errors influencing the sensitivity and/or specificity scores. A comparison with the 2009 data (Table 5) reveals that the sensitivity is at a comparable level. The specificity, however, is considerable lower than accounted in 2009.

Confusion of particles of different origin can influence negatively the specificity of the microscopic method. Besides known examples of confusion of terrestrial animal material with TCP, soya bean fragments or rape seed fragments, the current test reveals the possible confusion of blood particles with palm pit fragments (Figure 2).

Table 5 Results for detection of material of terrestrial animals and of fish in feed samples based on sediments of previous ring tests organised by J.S. Jørgensen (Danish Plant Directorate, Lyngby; 2003-2007) and RIKILT (2008-2018) on behalf of the IAG section Microscopy. Results have been communicated in the framework of the annual meetings this Section. Results indicate specificity in the case of the blank, and sensitivity in the case of the other sample types.

\begin{tabular}{|c|c|c|c|c|c|c|c|c|c|}
\hline Detection of : & \multicolumn{6}{|c|}{ Land animals } & \multicolumn{3}{|l|}{ Fish } \\
\hline Content: fish & 0 & $2-5 \%$ & $2 \%$ & 0 & $2 \%$ & 0 & 0 & 0 & 0 \\
\hline land animal & 0 & 0 & $0.1 \%$ & $0.1 \%$ & $0.05 \%$ & $\leq 0.05 \%$ & 0 & $0.1 \%$ & $\leq 0.05 \%$ \\
\hline $2004(n=30)$ & 0.93 & & & & & 0.97 & 0.97 & & 0.93 \\
\hline $2005(n=42)$ & & & 0.95 & 0.95 & & & & 0.76 & \\
\hline $2007(n=45)$ & & 0.89 & 0.93 & & & & & & \\
\hline $2008(n=45)$ & 0.93 & & & 0.98 & & 0.96 & 0.98 & 0.91 & 0.84 \\
\hline $2009(n=49)$ & 0.96 & 0.98 & & 1.0 & & & 0.96 & 0.88 & \\
\hline $2010(n=53)$ & 0.96 & & 0.98 & & 0.91 & & 0.98 & & \\
\hline $2014(n=52)$ & 0.96 & & 0.94 & & & & 0.96 & & \\
\hline $2015(n=42)$ & 0.95 & & & 0.93 & & & 0.88 & 0.90 & \\
\hline \multirow[t]{2}{*}{$2016(n=45)$} & 0.96 & & 0.96 & & & & 0.98 & & \\
\hline & & & 0.91 & & & & & & \\
\hline \multirow[t]{2}{*}{$2017(n=36)$} & 0.89 & & & & & $0.91^{2)}$ & 0.94 & & \\
\hline & 0.94 & & & & & & 0.97 & & \\
\hline $2018(n=43)$, current results & 0.91 & 0.84 & 0.95 & 1.0 & & & 0.93 & 0.95 & \\
\hline
\end{tabular}

1) TCP used as contaminant for land animal material

2) $0.01 \%$ of bone meal representing $0.03 \% \mathrm{MBM}$ 
In the view of the purpose of the current ring test (proficiency testing instead of a validation study), every laboratory is welcome to participate. A majority of participants (close to 75\%) has shown to be capable to implement and maintain the microscopic method. The current data indicating suboptimal values for both specificity and sensitivity for the detection of terrestrial animal material in feed is a direct result of the open participation of this ring test. Nevertheless, a further evaluation of some factors in the application of the microscopic method, such as a correct identification of particles and the methodological parameters influencing the identification (e.g. embedding agent and staining) might shed some light on the backgrounds of the current results.

\subsection{Application of the microscopic method}

The current microscopic method was introduced in 2013 (EC, 2013a). Although in previous years a decreasing number of participants had difficulties identifying the correct application of the method, especially the establishment of the correct number of cycles (2014: 33\% of the total participants applied incorrect number of cycles, 2015: 12\%, 2016: 13\%, 2017: 6\%; Table 6; van Raamsdonk et al., 2014, 2015, 2016, 2017), an incorrect number of cycles was applied by close to a quarter of the participants (23.3\%). These participants include both public as well as private laboratories. The report form of the IAG ring tests provides guidance when results have been entered by changing colour for the cycles still to perform (Annex 4). A comparable active report form could be extended to routine analyses.

The required embedding agent glycerol is still reported to be applied by a minority of participants (Table 6). This can be clarified by the difference in viscosity of glycerol (dynamic viscosity $1200 \mathrm{cP}$ ) and of paraffin oil (preferably 68-81 cP). A lower viscosity causes a faster penetration of embedding agent in the bone structure, resulting in a higher transparency of the bone mass. The drawback of paraffin oil, however, is the variety in the composition of alkanes and hence a variety of available versions with differing viscosities. Apart from the specific type of embedding agent, its viscosity will have influence on the way a slide should be handled and examined. The way of examination and the specific appearance of the particles might influence the performance of the method.

Table 6 Comparison between some parameter distributions in the IAG ring studies between 2008 and 2018. *: number of cycles since 2014.

\begin{tabular}{|c|c|c|c|c|}
\hline parameter & parameter choice & 2008 & $2009-2017$ & 2018 \\
\hline \multicolumn{3}{|l|}{ correct number of cycles $*$} & $67.3 \%-94.3 \%$ & $76.7 \%$ \\
\hline $\begin{array}{l}\text { share of the total sediment used for } \\
\text { examination }\end{array}$ & minimum & $4 \%$ & $0.2 \%-3 \%$ & $5 \%$ \\
\hline \multirow[t]{5}{*}{ embedding agent for sediment } & glycerine / glycerol & 8 & $10-25$ & 16 \\
\hline & paraffin oil & 18 & $12-23$ & 12 \\
\hline & Norland Adhesive & 0 & $2-7$ & 4 \\
\hline & chloral hydrate & 3 & $1-0$ & 0 \\
\hline & other (e.g. Depar 3000, water) & 8 & $5-0$ & 0 \\
\hline
\end{tabular}

In 2003 the minimum required amount of material used for sedimentation was raised from 2 to 5 grams (Commission Directive 2003/126/EC). The renewed and current method of 2013 states the amount of 10 grams as basis for sedimentation (Regulation (EC) 51/2013 amending Regulation (EC) 152/2009). These improvements were made in the view of increasing the sensitivity of the microscopic method. The SOP for guidance for preparing slides mentions the use of $10 \mathrm{mg}$ as example for the amount of material for the preparation of a slide. Usually the amount of sediment produced after sedimentation of 10 grams of sample material is (much) higher. In the previous versions of the IAG ring tests amounts as low as $0.2-4 \%$ of the sediment material available has been declared as being used. Consider the situation that an amount of $200 \mathrm{mg}$ of sediment material results from sedimentation of 10 grams of sample material, which is an average amount for ruminant and pig feeds. Based on the recommendation of $10 \mathrm{mg}$ per slide, and in the need of preparing and evaluating four slides of the sediment material per cycle, an approximate amount of $40 \mathrm{mg}$ of sediment material 
will be examined. This accounts for $20 \%$ of the original amount of sediment material, which logically represents 2 grams of original sample material. This amount is identical to the 2 grams considered insufficient in the year 2003, which has been raised twice since then in order to improve the sensitivity. The second factor is the high diversity in amount of sediment material obtained. A factor three among the lowest and highest amount was found in the data submitted by the participants. Both the diversity in the share of the sediment material used and the amount obtained after sedimentation indicate a lack of harmonization in the way the microscopic method is implemented.

The practical implementation of several parameters might have their influence on both specificity and sensitivity. It is recommended to invest in expertise and documentation for the proper discrimination of particles of animal origin, as far as required by legislation to be recognised, in comparison with all types of confusing material from other origins.

\subsection{PCR}

Although the design of the current ring test was assumed to be relatively straightforward for the microscopic method, the application of PCR appeared to be more complicated. The bakery by-products appeared to contain ruminant DNA at a well detectable level. The issue of detecting authorised products of ruminant origin, such as milk and milk products, extends apparently to other products which might contain ruminant DNA of authorised origin. This implies that reuse of by-products of the food production chain, which is increasingly important in the framework of circular economy, might have consequences for monitoring the feed ban for PAPs of ruminant origin.

The presence of blood material as assumed by one of the participants, which is prohibited in feed for terrestrial animals if originating from ruminants, combined with a positive signal for ruminant DNA could indeed result in the conclusion of presence of terrestrial animal material. None of the samples was labelled as feed for aquaculture, which implied that microscopy was the first method to be applied for all four samples (Standard Operational Procedure (SOP) "Operational schemes v3.0"). In those cases it is important to properly detect components which could interfere with a correct conclusion. However, blood material might be difficult to detect (Veys et al., 2018; Figure 2), and only six out of 23 participants analysing the composition of sample A detected the bakery by-products (unpublished results).

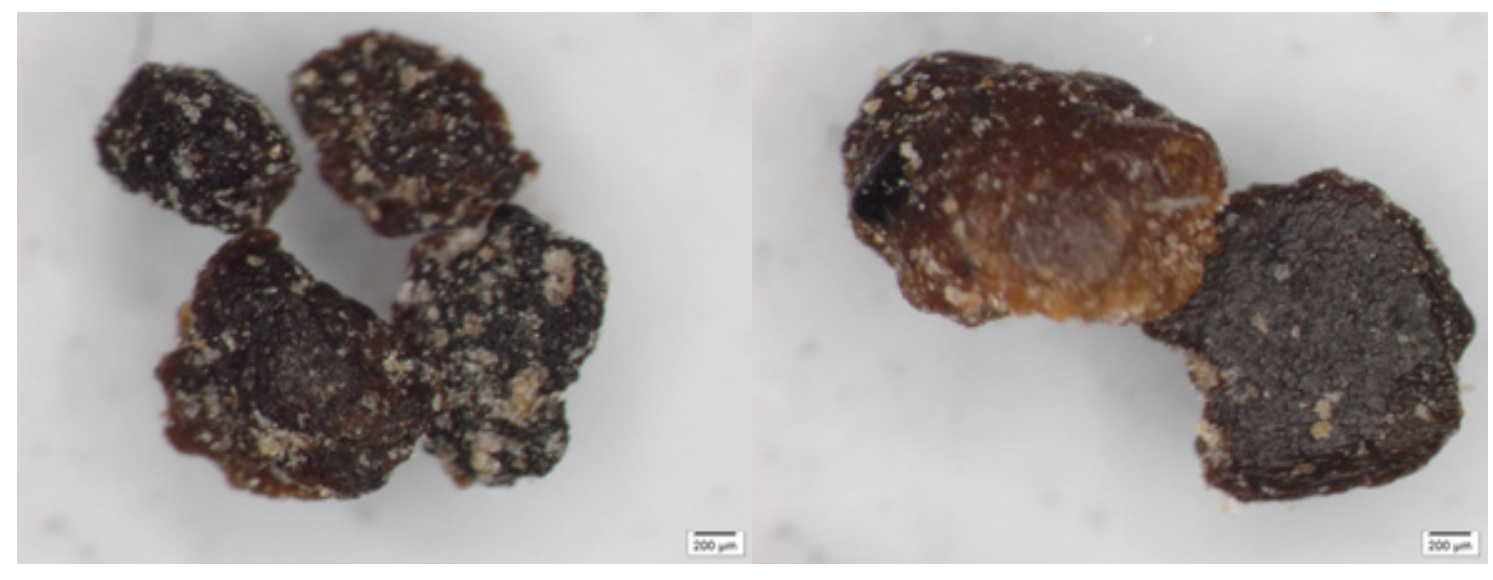

Figure 2 Examples of assumed blood particles (left) and palm pit expellers (right). 


\section{Conclusions and recommendations}

\subsection{Conclusions}

The composition of the samples in the current ring test should allow the participants to demonstrate their performance under legal requirements $(0.1 \% \mathrm{w} / \mathrm{w})$ : two samples with ruminant material spiked at the legal technical requirement for monitoring methods in the presence and absence of fish material $(2 \% \mathrm{w} / \mathrm{w})$, and two additional samples without terrestrial animal material with the same conditions for fish material. The two samples containing fish material could be considered to mimic feed for aquaculture.

The total overview of results for the microscopic method shows suboptimal values for both specificity and sensitivity situations. Four participants and three participants, respectively, reported particles of terrestrial animals or of fish material in the blank sample 2018-B. The results indicate that certain particles can be erroneously identified as animal material, and confusing particles of animal origin can be overlooked. Numbers of particles less than the maximum number possible in the report form per cycle (16) pertain primarily to terrestrial animal material in the presence of fish meal.

The EU PCR method for detection of ruminant material works perfectly at a spike level of $0.1 \%(w / w)$. The detection of $3 \%$ of bakery by-products, part of the pig feed, by most participants adds to the complicating situation that presence of authorised ruminant material containing DNA results in positive signals. The list of recognised sources such as milk and milk products, and ruminant gelatine can be extended with bakery by-products, which is important for the recycling of food by-products.

\subsection{Recommendations}

- The documentation for and training of microscopists for correct identification of particles of animal origin would deserve further attention in order to guard specificity.

- Evaluation of several aspects of the application of the current microscopic methods would be beneficial for improving harmonization among the laboratories applying the microscopic method. 


\section{Acknowledgements}

The board of IAG section Feeding Stuff Microscopy (dr. G. Frick (ALP, Posieux), ir. J. Vancutsem (FAVV, Tervuren), dr. R. Weiss (AGES, Vienna), dr. R. Krull-Wöhrmann (CVUA-RRW, Krefeld)) supported this study as advisory board for communication with the scientists and laboratories working in this research field, and in the final report activities. Their contributions are greatly acknowledged. Thanks to colleagues dr. L. van der Geest, dr. J. de Jong and dr. A. Peijnenburg for the internal RIKILT review procedure. 


\section{References}

Engling, F.-P., J.S. Jørgensen, I. Paradies-Severin \& H. Hahn, 2000. Evidence of animal meal in feeds. Kraftfutter / Feed Magazine 2000(1): 14-17.

European Commission, 2009. Commission Regulation (EC) No 152/2009 of 27 January 2009 laying down the methods of sampling and analysis for the official control of feed. Official Journal of the European Communities L 54, 26.2.2009, p. 1-130.

European Commission, 2013a. Commission Regulation (EU) No 51/2013 of 16 January 2013 amending Regulation (EC) No 152/2009 as regards the methods of analysis for the determination of constituents of animal origin for the official control of feed Text with EEA relevance. Official Journal of the European Communities L 20, 23.1.2013, p. 33-43.

European Commission, 2013b. Corrigendum to Commission Regulation (EU) No 51/2013 of 16 January 2013 amending Regulation (EC) No 152/2009 as regards the methods of analysis for the determination of constituents of animal origin for the official control of feed (OJ $L 20$, 23.1.2013). Official Journal of the European Communities $L 62,6.3 .2013$, p. 36-36.

European Commission, 2013c. Commission Regulation (EU) No 56/2013 of 16 January 2013 amending Annexes I and IV to Regulation (EC) No 999/2001 of the European Parliament and of the Council laying down rules for the prevention, control and eradication of certain transmissible spongiform encephalopathies Text with EEA relevance. Official Journal of the European Communities L 21, 24.1.2013, p. 3-16.

European Union, 2001. Regulation (EC) No. 999/2001 of the European Parliament and of the Council of 22 May 2001 laying down rules for the prevention, control and eradication of certain transmissible spongiform encephalopathies. Official Journal of the European Communities L 147, $1-40$.

Lindenmayer, M.A.; Burgman, 2005. Monitoring, assessment and indicators. Practical Conservation Biology (PAP/CDR ed.). Collingwood, Victoria, Australia: CSIRO Publishing. pp. 401-424.

Raamsdonk, L.W.D. van, T.W. Prins, N. van de Rhee, J.J.M. Vliege, V.G.Z. Pinckaers, $2017 \mathrm{~b}$. Microscopic recognition and identification of fish meal in compound feeds. Food Additives and Contaminants, 34(8): 1364-1376. http://www.tandfonline.com/doi/full/10.1080/19440049.2017.1283711

Raamsdonk, L.W.D. van, W. Hekman, J.M. Vliege, V. Pinckaers, S.M. van Ruth, 2009. Animal proteins in feed. IAG ring test 2009. Report 2009.017, RIKILT, Wageningen, 34 pp. http://edepot.wur.nl/132981

Raamsdonk, L.W.D. van, V.G.Z. Pinckaers, I.M. Scholtens, T.W. Prins, H. van der Voet, J.J.M. Vliege, 2014. IAG ring test animal proteins 2014. Report 2014.011. RIKILT, Wageningen, pp. 39.

Raamsdonk, L.W.D. van, J.J.M. Vliege, C.P.A.F. Smits, V.G.Z. Pinckaers, 2017a. IAG ring test animal proteins 2017. Report 2017.012. RIKILT, Wageningen, pp. 34. http://dx.doi.org/10.18174/431755

Veys, P., G. Berben and V. Baeten, 2010. CRL-AP Proficiency Test 2009. Centre Wallon de Recherches Agronomiques, Gembloux (BE). ISBN 278-2-87286-073-9.

European Union Reference Laboratory, SOPs: http://eurl.craw.eu/index.php?page=187 


\section{Annex 1 Introduction to the test}

\section{Test 2018-A: animal proteins in feed}

The IAG ring test animal proteins in feeds is designed to apply both the microscopic method and the PCR ruminant method. The procedures to be followed are described in Annex VI of Regulation (EC) $152 / 2009$ from the European Union, amended by (EC) $51 / 2013$, and the related SOPs. All the documentation can be found on the website of the EURL AP: http://eurl.craw.eu/index.php?page=187. The jars contain 50 gram of feed, which is sufficient for carrying out three cycles of the microscopic method and/or for carrying out the PCR analysis, if necessary according to the SOPs. Take care to homogenise the content of each vial before taking the amount for analysis. The samples are prepared in such a way that you can start with the procedure as described in "EURL-AP SOP operational schemes", followed by the procedure in paragraph 2.1.3.4: use 10 grams for sedimentation etc. The process of analysis as included in this ring test will stop at the beginning of paragraph 2.1.5: the reporting sentences will not be used. Instead, the report form allows you to enter the number of particles per determination cycle.

Differentiation has to be made between particles of terrestrial animals (bone fragments, hairs, feathers) and those of fish (fish bone fragments, scales, gills, otholiths). If more than 16 fragments per category are found in any cycle, just choose "16" from the drop-down list.

Based on the average number of particles found, you have to make the decision whether each of the two types is absent in a sample (zero particles on average), below threshold (between 1 and 5 particles on average) or present ( 6 or more particles on average).

In addition to the work flow as presented in the paragraphs 2.1.3.4 until and including 2.1.4.3, it is mandatory to weight the sediment BEFORE and AFTER the analysis as performed in every determination.

All results can be entered in the report form with "animal proteins" in the name, which will be send to you separately. 


\section{Annex 2 Basic instructions for the test procedure}

\section{IAG ring test 2018 animal proteins}

Instructions for the IAG ring test

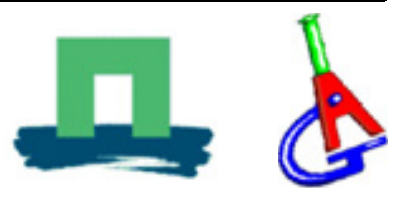

1 You have received a box with an introduction letter and four vials containing 50 grams of possibly contaminated animal feed. Please report the receipt of your package as soon as possible by E-mail to the address mentioned below.

2 The samples have to be analysed according to Annex VI of Regulation (EC) 152/2009 from the European Union, modified by (EC) 51/2013. The consolidated version and the SOPs can be found on the EURL website. The sample design allows to carry out the PCR ruminant analysis, but follow the SOPs carefully!. Take care to homogenise the content of each vial before taking the amount for analysis.

The samples are prepared in such a way that you can start with the procedure in paragraph 2.1.3.4: use 10 grams for sedimentation etc. The sample amount allows you to analyse three determinations of 10 grams as indicated in paragraph 2.1.4.3. The process of analysis as included in this ring test will stop at the beginning of paragraph 2.1.5: the reporting sentences will not be used. Instead, the report form allows you to enter the number of particles per determination cycle and a final conclusion.

Differentiation has to be made between particles of terrestrial animals (bone fragments, hairs, horn, skin, feathers) and those of fish (fish bone fragments, scales, gills, otholiths). If more than 16 particles are found in any category, please enter the value 16.

The report form is interactive: if the results in the first determination cycle make it necessary to perform a second or third analysis according to the requirements of the Regulation, additional cells will turn pink.

The final conclusion, according to Regulation (EC) 152/2009, can be reported in three ways, depending on the average number of particles found per category:

= Zero particles: animal proteins absent. If the first determination reveals no particles in any category, a second determination is not necessary.

$=$ More than 5 particles on average per determination: present.

= Between 1 and 5 particles on average: sample is positive but a risk of a false positive result cannot be excluded. For the sake of the framework of the current report form the term 'suspect' has to be chosen.

Click here for the Regulation and connected SOPS

3 Reporting consists of the following steps:

3a Please fill in the questionnaire on the page "Procedure".

Most of the cells contain a drop-down list. These lists can be used to select an answer as follows. When clicking on a cell, the cursor changes into a hand. A second click will open the drop-down list.

Your unique lab number is mentioned in the introduction letter, enclosed in the box. All the fields with a drop-down list have to be completed.

3b Please enter your results in the fields at page "Results". Your unique lab number automatically shows up after your have entered it at the page Procedure. Enter yourself the four unique labels of the vials. 
All fields with a drop-down list have to be completed. Please add the exact sediment weight in milligrams, without a decimal sign, of the total amount just before analysis and the remaining amount just after analysis.

4 After completing the two forms "Procedure" and "Results", they have to be sent to the organisers in two ways:

4a Save the Excel file by using "Save as ...", add your unique lab code to the end of name (replace the \#\# signs with your lab number). The forms have to be sent by E-mail as Excel file and as a scan (*.PDF) to leo.vanraamsdonk@wur.nl AND to microscopie.rikilt@wur.nl.

4b Results will be included in the final analyses and report only if both forms are send in by electronic mail, and after the proper receipt of the requested fee.

5 Direct any questions to leo.vanraamsdonk@wur.nl

6 Closing date is Friday April 23rd, 2018. 


\section{Annex 3 Report form for procedure details}

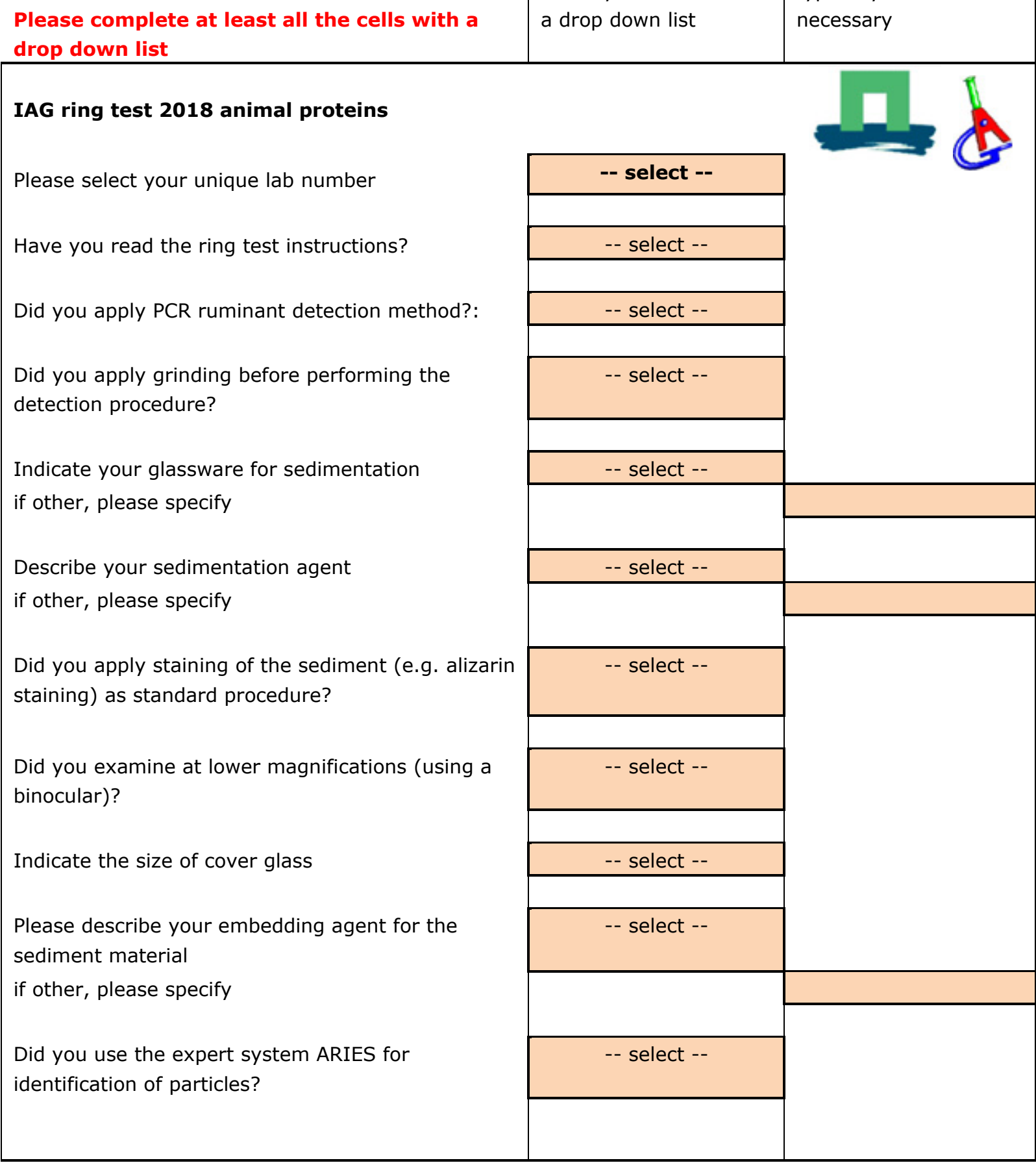




\section{Annex 4 Report form: results}

Please complete all the cells which are pink coloured. Additional cells will turn pink depending on your results. If more than 16 particles were found in any category, please enter the value 16.

\section{IAG ring test 2017 animal proteins}

lab number

sample number

\section{First determination}

weight of sediment before analyses (in $\mathrm{mg}$ ) weight of sediment after analyses (in $\mathrm{mg}$ ) sediment \% used for analyses

Result of first determination cycle

\section{Second determination}

\section{Third determination}

Total number of particles per category
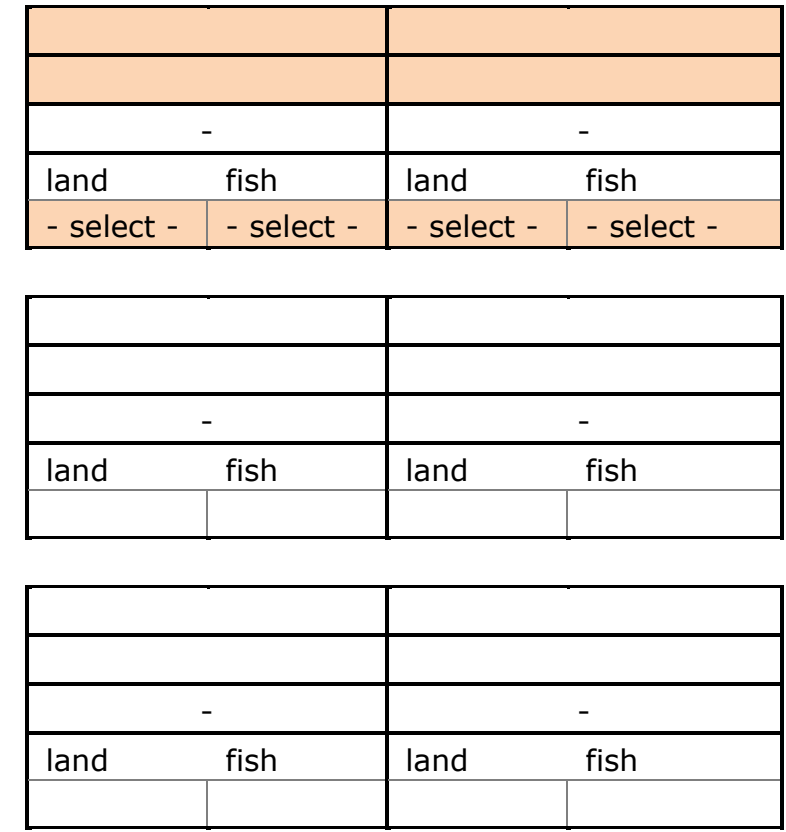

\begin{tabular}{l|l|l|l}
0 & 0 & 0 & 0 \\
\hline
\end{tabular}

\section{PCR results}

Ruminant (EURL method)

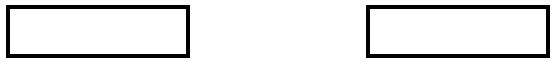

\section{Final conclusion}

Type of particles

Comment, if necessary

\begin{tabular}{|l|l|l|l|}
\hline \multicolumn{2}{|l|}{ land } & \multicolumn{1}{l|}{ land } & \multicolumn{1}{l|}{ fish } \\
\hline - select - & - select - & - select - & - select - \\
\hline & & & \\
& & & \\
& & & \\
\hline
\end{tabular}




\section{Annex 5 List of participants}

\begin{tabular}{|c|c|}
\hline Institute & Country \\
\hline Austrian Agency for Health and Food Safety-AGES & Austria \\
\hline Laboratorium ECCA nv & Belgium \\
\hline FLVVT & Belgium \\
\hline LFSAL & Belgium \\
\hline Croatian Veterinary Institute & Croatia \\
\hline Danish Veterinary and Food Administration & Denmark \\
\hline Laboratoire Départemental d'Analyse \& de Recherche & France \\
\hline Inovalys-Nantes & France \\
\hline S.C.L. Laboratoire de Rennes & France \\
\hline WESSLING GmbH & Germany \\
\hline $\begin{array}{l}\text { Staatliche Betriebsgesellschaft für Umwelt und Landwirtschaft, GB6-Labore } \\
\text { Landwirtschaft / LUFA, FB62 }\end{array}$ & Germany \\
\hline Landeslabor Berlin-Brandenburg & Germany \\
\hline CVUA-RRW & Germany \\
\hline LUFA-Speyer & Germany \\
\hline Futtermittelinstitut Stade (LAVES) & Germany \\
\hline LLFG Landesanstalt für Landwirtschaft & Germany \\
\hline LUFA Nord-West & Germany \\
\hline Landesbetrieb Hessisches Landeslabor, Landwirtschaft und Umwelt & Germany \\
\hline Bayerisches Landesamt fur Gesundheit und Lebensmittelsicherheit & Germany \\
\hline SYNLAB Umweltinstitut GmbH, Lebensmittelinstitut Jena & Germany \\
\hline LUFA Rostock & Germany \\
\hline LTZ Augustenberg & Germany \\
\hline SGS Germany GmbH & Germany \\
\hline Thüringer Landesanstalt für Landwirtschaft Jena & Germany \\
\hline Equine Centre & Ireland \\
\hline Department of Agriculture, Fisheries and Food, Backweston Agri Laboratories & Ireland \\
\hline Ministero delle politiche agricole alimentari e forestali, Laboratorio di Modena & Italy \\
\hline Nutreco Nederland BV - Masterlab & Netherlands \\
\hline Eurofins Food Testing Rotterdam BV & Netherlands \\
\hline CCL - Nutricontrol & Netherlands \\
\hline TLR & Netherlands \\
\hline Nofima AS & Norway \\
\hline Alcontrol Stjørdal & Norway \\
\hline NSF INASSA S.A.C. & Peru \\
\hline Baltic control CMA S.A. & Peru \\
\hline Cargill Poland & Poland \\
\hline Instytut Zootechniki Szczecin, Panstwowy Institut Badawczy & Poland \\
\hline Lab. Regional de Veterinária & Portugal \\
\hline $\begin{array}{l}\text { University of Ljubljana, Veterinary Faculty, Natl. Veterinary Institute, Unit for } \\
\text { Pathology of Animal Nutrition and Environmental Hygiene }\end{array}$ & Slovenia \\
\hline Dirección General de Produccion Agropecuaria, Laboratorio Agrario Regional & Spain \\
\hline $\begin{array}{l}\text { Laboratorio arbitral agroaumentario minesterio de agrecultura y pesco } \\
\text { aumentauon y medioambiente }\end{array}$ & Spain \\
\hline Trouw nutrition Espana & Spain \\
\hline National Veterinary Institute, SVA & Sweden \\
\hline Agroscope (ALP), Swiss Research Station & Switzerland \\
\hline CPF (Thailand) Public Company Limited & Thailand \\
\hline
\end{tabular}




\section{Annex 6 Details of procedures applied, microscopic method}

\begin{tabular}{|c|c|c|c|c|c|c|c|c|}
\hline \multirow[t]{2}{*}{ lab } & \multicolumn{8}{|l|}{ prior } \\
\hline & grinding & glassware & agent & staining & binocular & size & embedding & ARIES \\
\hline 1 & yes & special conical glass with cock & TCE & no & yes & small $(21 \times 26 \mathrm{~mm})$ & glycerine & yes \\
\hline 3 & no & chemical sedimentation funnel & TCE & no & yes & small $(20 \times 20 \mathrm{~mm})$ & glycerine & no \\
\hline 5 & yes & chemical sedimentation funnel & TCE & yes & no & small $(20 \times 20 \mathrm{~mm})$ & glycerine & no \\
\hline 6 & no & beaker (flat bottom) & TCE & no & yes & small $(20 \times 20 \mathrm{~mm})$ & immersion oil & no \\
\hline 7 & no & beaker (flat bottom) & TCE & no & no & medium & paraffin oil & no \\
\hline 8 & yes & special conical glass with cock & TCE & no & yes & small $(20 \times 20 \mathrm{~mm})$ & glycerine & no \\
\hline 10 & no & conical champagne glass & TCE & no & yes & small $(20 \times 20 \mathrm{~mm})$ & paraffin oil & no \\
\hline 11 & no & chemical sedimentation funnel & TCE & yes & yes & medium & immersion oil & no \\
\hline 13 & no & chemical sedimentation funnel & TCE & no & yes & small $(21 \times 26 \mathrm{~mm})$ & paraffin oil & no \\
\hline 14 & no & special conical glass with cock & TCE & no & no & small $(21 \times 26 \mathrm{~mm})$ & immersion oil & no \\
\hline 15 & no & beaker (flat bottom) & TCE & no & no & small $(20 \times 20 \mathrm{~mm})$ & glycerine & no \\
\hline 16 & yes & chemical sedimentation funnel & TCE & no & yes & small $(20 \times 20 \mathrm{~mm})$ & immersion oil & no \\
\hline 18 & no & chemical sedimentation funnel & TCE & no & yes & small $(20 \times 20 \mathrm{~mm})$ & paraffin oil & no \\
\hline 19 & no & other & TCE & no & no & large $(26 \times 50 \mathrm{~mm})$ & paraffin oil & no \\
\hline 21 & yes & chemical sedimentation funnel & TCE & yes & yes & large $(26 \times 50 \mathrm{~mm})$ & paraffin oil & yes \\
\hline 22 & no & beaker (flat bottom) & chloroform & no & yes & small $(20 \times 20 \mathrm{~mm})$ & immersion oil & no \\
\hline 23 & no & conical champagne glass & TCE & no & yes & large $(22 \times 50 \mathrm{~mm})$ & immersion oil & no \\
\hline 24 & no & chemical sedimentation funnel & TCE & yes & yes & small $(20 \times 20 \mathrm{~mm})$ & glycerine & no \\
\hline 25 & yes & other & TCE & no & no & small $(20 \times 20 \mathrm{~mm})$ & glycerine & no \\
\hline 27 & no & chemical sedimentation funnel & TCE & yes & yes & small $(20 \times 20 \mathrm{~mm})$ & glycerine & no \\
\hline 28 & no & conical champagne glass & TCE & no & yes & small $(20 \times 20 \mathrm{~mm})$ & immersion oil & no \\
\hline 29 & no & chemical sedimentation funnel & TCE & no & no & & paraffin oil & no \\
\hline 30 & no & chemical sedimentation funnel & TCE & no & yes & small $(20 \times 20 \mathrm{~mm})$ & paraffin oil & no \\
\hline 31 & yes & chemical sedimentation funnel & TCE & yes & yes & small $(20 \times 20 \mathrm{~mm})$ & Norland adhesive 65 & no \\
\hline 33 & no & chemical sedimentation funnel & TCE & yes & no & small $(20 \times 20 \mathrm{~mm})$ & Norland adhesive 65 & no \\
\hline
\end{tabular}




\begin{tabular}{lll}
\hline lab & prior & \\
\hline 34 & no & conical champagne glass \\
\hline 35 & no & special conical glass with cock \\
\hline 36 & no & special conical glass with cock \\
\hline 37 & no & chemical sedimentation funnel \\
\hline 38 & no & chemical sedimentation funnel \\
\hline 39 & no & chemical sedimentation funnel \\
\hline 40 & no & beaker (flat bottom) \\
\hline 41 & no & conical champagne glass \\
\hline 42 & no & \\
\hline 45 & no & chemical sedimentation funnel \\
\hline 46 & no & conical champagne glass \\
\hline 48 & no & conical champagne glass \\
\hline 49 & no & \\
\hline 51 & no & conical champagne glass \\
\hline
\end{tabular}

$\begin{array}{lll}\text { TCE } & \text { no } & \text { yes } \\ \text { TCE } & \text { yes } & \text { no } \\ \text { TCE } & \text { yes } & \text { yes } \\ \text { TCE } & \text { yes } & \text { yes } \\ \text { TCE } & \text { no } & \text { ye } \\ \text { TCE } & \text { yes } & \text { yes } \\ \text { TCE } & \text { yes } & \text { yes } \\ \text { TCE } & \text { no } & \text { ye } \\ \text { TCE } & \text { yes } & \text { ye } \\ \text { TCE } & \text { no } & \text { ye } \\ \text { TCE } & \text { no } & \text { ye } \\ \text { TCE } & \text { yes } & \text { ye } \\ & & \\ \text { TCE } & \text { no } & \text { ye } \\ \text { TCE } & \text { yes } & \text { no } \\ \text { TCE } & \text { no } & \text { ye }\end{array}$

$\begin{array}{ll}\text { yes } & \\ \text { no } & \\ \text { yes } & \\ \text { yes } & \\ \text { yes } & \\ \text { yes } & \text { smes } \\ \text { yes } & \text { yes } \\ \text { yes } & \text { sm } \\ \text { yes } & \text { sma }\end{array}$

small $(20 \times 2$

large $(22 \times 50 \mathrm{~mm})$

small $(20 \times 20 \mathrm{~mm})$

medium

small $(20 \times 20 \mathrm{~mm})$

small $(20 \times 20 \mathrm{~mm})$

small $(20 \times 20 \mathrm{~mm})$

small $(20 \times 20 \mathrm{~mm})$

small $(21 \times 26 \mathrm{~mm})$

small $(20 \times 20 \mathrm{~mm})$

yes small $(20 \times 20 \mathrm{~mm})$

small $(20 \times 20 \mathrm{~mm})$

no small $(20 \times 20 \mathrm{~mm})$

small $(20 \times 20 \mathrm{~mm})$

yos

glycerine

paraffin oil

no

glycerine no

paraffin oil

no

Norland adhesive 65

glycerine no

glycerine

immersion oil

immersion oil no

glycerine no

paraffin oil

immersion oil

no

immersion

no

no

65 no

no 


\section{Annex 7 Results: presence of animal proteins, microscopic detection}

\begin{tabular}{|c|c|c|c|c|c|c|c|c|c|c|c|c|c|}
\hline \multirow[t]{2}{*}{ lab nr } & & & & & \multicolumn{3}{|c|}{ land } & \multirow[b]{2}{*}{ c } & \multirow[b]{2}{*}{ D } & \multicolumn{3}{|l|}{ fish } & \multirow[b]{2}{*}{ D } \\
\hline & PCR & & & & & A & B & & & A & B & c & \\
\hline 1 & no & 261 & 92 & 228 & 79 & absent & absent & present & present & present & absent & present & absent \\
\hline 3 & yes & 96 & 237 & 188 & 134 & suspect & absent & present & present & present & absent & present & absent \\
\hline 4 & no & 56 & 132 & 148 & 89 & absent & absent & present & present & present & absent & present & absent \\
\hline 5 & no & 221 & 67 & 128 & 194 & absent & absent & present & present & present & absent & present & absent \\
\hline 6 & no & 141 & 112 & 8 & 219 & absent & absent & present & present & present & absent & present & absent \\
\hline 7 & no & 171 & 222 & 63 & 119 & absent & absent & present & present & present & absent & present & absent \\
\hline 10 & yes & 241 & 97 & 143 & 129 & absent & absent & present & present & present & absent & present & absent \\
\hline 11 & no & 216 & 72 & 158 & 254 & absent & absent & present & present & present & absent & present & absent \\
\hline 13 & no & 1 & 82 & 233 & 209 & absent & absent & present & present & present & absent & present & absent \\
\hline 14 & yes & 116 & 87 & 138 & 234 & absent & absent & present & present & present & absent & present & absent \\
\hline 15 & no & 166 & 57 & 213 & 74 & absent & absent & present & present & present & absent & present & absent \\
\hline 16 & yes & 191 & 127 & 243 & 69 & absent & absent & present & present & present & absent & present & absent \\
\hline 18 & no & 126 & 142 & 178 & 169 & absent & absent & present & present & present & absent & present & absent \\
\hline 19 & yes & 251 & 42 & 88 & 204 & suspect & absent & present & present & present & absent & present & absent \\
\hline 21 & yes & 186 & 107 & 133 & 259 & absent & absent & present & present & present & absent & present & absent \\
\hline 22 & yes & 101 & 152 & 13 & 39 & suspect & present & present & present & present & absent & present & absent \\
\hline 23 & yes & 71 & 117 & 263 & 239 & absent & absent & present & present & present & absent & present & absent \\
\hline 24 & yes & 151 & 182 & 168 & 159 & absent & absent & present & present & present & absent & present & absent \\
\hline 25 & yes & 236 & 207 & 193 & 84 & absent & absent & present & present & present & absent & present & absent \\
\hline 27 & yes & 41 & 247 & 53 & 94 & absent & absent & present & present & present & absent & present & absent \\
\hline 28 & no & 146 & 192 & 108 & 104 & absent & absent & absent & present & present & absent & present & absent \\
\hline 29 & no & 11 & 242 & 118 & 229 & absent & absent & present & present & present & absent & present & absent \\
\hline 30 & no & 16 & 252 & 58 & 199 & absent & absent & present & present & present & absent & present & absent \\
\hline 31 & yes & 31 & 177 & 183 & 149 & absent & absent & present & present & present & absent & present & absent \\
\hline 33 & yes & 36 & 257 & 73 & 264 & absent & absent & present & present & present & absent & present & absent \\
\hline
\end{tabular}




\begin{tabular}{|c|c|c|c|c|c|c|c|c|c|c|c|c|c|}
\hline \multirow[t]{2}{*}{ lab nr } & \multirow[b]{2}{*}{ PCR } & & & & \multicolumn{3}{|c|}{ land } & \multirow[b]{2}{*}{ c } & \multirow[b]{2}{*}{ D } & \multicolumn{3}{|l|}{ fish } & \multirow[b]{2}{*}{ D } \\
\hline & & & & & & A & B & & & A & B & C & \\
\hline 34 & no & 6 & 162 & 3 & 144 & present & suspect & present & present & present & absent & present & absent \\
\hline 35 & no & 76 & 122 & 23 & 99 & absent & absent & absent & suspect & suspect & absent & present & absent \\
\hline 36 & no & 66 & 217 & 198 & 4 & absent & absent & present & present & present & absent & present & absent \\
\hline 37 & yes & 106 & 202 & 123 & 34 & absent & absent & present & present & present & absent & present & absent \\
\hline 38 & no & 81 & 212 & 38 & 44 & absent & absent & present & present & present & absent & present & absent \\
\hline 39 & no & 201 & 27 & 238 & 24 & absent & absent & present & present & present & absent & present & absent \\
\hline 40 & no & 51 & 157 & 98 & 244 & absent & absent & suspect & present & present & absent & present & absent \\
\hline 41 & no & 21 & 262 & 248 & 189 & absent & absent & present & present & present & absent & present & absent \\
\hline 42 & no & 26 & 267 & 203 & 139 & absent & absent & present & present & present & absent & present & absent \\
\hline 43 & yes & 61 & 187 & 43 & 9 & present & present & present & present & present & present & present & absent \\
\hline 45 & no & 256 & 52 & 103 & 59 & absent & absent & suspect & present & present & absent & present & absent \\
\hline 46 & no & 196 & 227 & 163 & 109 & suspect & absent & present & suspect & present & suspect & present & suspect \\
\hline 47 & yes & 206 & 147 & 218 & 124 & suspect & suspect & suspect & present & present & absent & present & absent \\
\hline 48 & yes & 131 & 172 & 48 & 249 & absent & absent & present & present & present & absent & present & absent \\
\hline 49 & yes & 91 & 102 & 153 & 14 & absent & absent & present & present & present & absent & present & absent \\
\hline 51 & no & 136 & 37 & 223 & 29 & absent & absent & suspect & present & present & suspect & present & suspect \\
\hline
\end{tabular}




\section{Annex 8 Results: reporting details and evaluation, microscopic detection}

\section{Explanation:}

Blue cells: incorrect number of determination cycles; pink cells: incorrect findings (false positives or false negatives).

Codes for evaluation:

A: participants with correct indications of 15 or 16 particles, found after one determination cycle.

B: participants with correct indications of 6 to 14 particles for one or more samples, found after any number of determination cycles.

C: participants with a low sensitivity (lower than or equal to 5 particles) for one or more samples.

D: participants with one or more false positive indications.

$\mathrm{E}$ : participants with incorrect number of determination cycles for at least one sample.

For all indications in the categories $C$ and D the participant's final conclusion is given ( $p$ : present; S: suspect; a: absent; - (hyphen): no final conclusion given). Final conclusions violating the number of particles are marked yellow.

\begin{tabular}{|c|c|c|c|c|c|c|c|c|c|c|c|c|c|c|c|c|c|}
\hline \multirow[t]{2}{*}{ lab } & \multicolumn{4}{|c|}{$\%$ sed } & \multicolumn{4}{|c|}{ \#det. cycles } & \multicolumn{4}{|c|}{ \#terr } & \multicolumn{4}{|c|}{ \#fish } & \multirow[t]{2}{*}{ EVAL } \\
\hline & A & B & C & D & A & B & c & D & A & B & C & D & A & B & C & D & \\
\hline 1 & 45 & 56 & 55 & 74 & 1 & 1 & 1 & 1 & 0 & 0 & 15 & 16 & 16 & 0 & 16 & 0 & A \\
\hline 7 & 100 & 100 & 100 & 100 & 1 & 1 & 1 & 1 & 0 & 0 & 16 & 16 & 16 & 0 & 16 & 0 & A \\
\hline 13 & 15 & 33 & 27 & 34 & 1 & 1 & 1 & 1 & 0 & 0 & 16 & 16 & 16 & 0 & 16 & 0 & A \\
\hline 14 & 12 & 9 & 14 & 24 & 1 & 1 & 1 & 1 & 0 & 0 & 16 & 16 & 16 & 0 & 16 & 0 & A \\
\hline 15 & 25 & 22 & 21 & 31 & 1 & 1 & 1 & 1 & 0 & 0 & 16 & 16 & 16 & 0 & 16 & 0 & A \\
\hline 16 & 10 & 15 & 10 & 11 & 1 & 1 & 1 & 1 & 0 & 0 & 16 & 16 & 16 & 0 & 16 & 0 & A \\
\hline 18 & 34 & 27 & 22 & 27 & 1 & 1 & 1 & 1 & 0 & 0 & 16 & 16 & 16 & 0 & 16 & 0 & A \\
\hline 20 & 6 & 6 & 5 & 9 & 1 & 1 & 1 & 1 & 0 & 0 & 16 & 16 & 16 & 0 & 16 & 0 & A \\
\hline 21 & 45 & 45 & 38 & 42 & 1 & 1 & 1 & 1 & 0 & 0 & 16 & 16 & 16 & 0 & 16 & 0 & A \\
\hline 24 & 70 & 66 & 72 & 68 & 1 & 1 & 1 & 1 & 0 & 0 & 16 & 16 & 16 & 0 & 16 & 0 & A \\
\hline 25 & 33 & 34 & 22 & 30 & 1 & 1 & 1 & 1 & 0 & 0 & 16 & 16 & 16 & 0 & 16 & 0 & A \\
\hline 27 & 22 & 18 & 17 & 17 & 1 & 1 & 1 & 1 & 0 & 0 & 16 & 16 & 16 & 0 & 16 & 0 & A \\
\hline 31 & 41 & 42 & 68 & 41 & 1 & 1 & 1 & 1 & 0 & 0 & 16 & 16 & 16 & 0 & 16 & 0 & A \\
\hline
\end{tabular}




\begin{tabular}{|c|c|c|c|c|c|c|c|c|c|c|c|c|c|c|c|c|c|c|c|c|c|c|c|}
\hline \multirow[t]{2}{*}{ lab } & \multicolumn{4}{|c|}{ \%sed } & \multicolumn{4}{|c|}{ \#det. cycles } & \multicolumn{8}{|c|}{ \#terr } & \multicolumn{6}{|l|}{ \#fish } & \multirow[t]{2}{*}{ EVAL } \\
\hline & A & B & C & D & A & B & c & D & A & & B & & C & & D & & $A$ & B & & c & D & & \\
\hline 36 & 100 & 100 & 100 & 100 & 1 & 1 & 1 & 1 & 0 & & 0 & & 16 & & 16 & & 16 & 0 & & 16 & 0 & & A \\
\hline 37 & 54 & 50 & 30 & 45 & 1 & 1 & 1 & 1 & 0 & & 0 & & 16 & & 16 & & 16 & 0 & & 16 & 0 & & A \\
\hline 39 & - & - & - & - & 1 & 1 & 1 & 1 & 0 & & 0 & & 16 & & 16 & & 16 & 0 & & 16 & 0 & & A \\
\hline 41 & - & 11 & 17 & 23 & 1 & 1 & 1 & 1 & 0 & & 0 & & 16 & & 16 & & 16 & 0 & & 16 & 0 & & A \\
\hline 49 & 100 & 100 & 100 & 100 & 1 & 1 & 1 & 1 & 0 & & 0 & & 16 & & 16 & & 16 & 0 & & 16 & 0 & & A \\
\hline 4 & 12 & 16 & 13 & 15 & 1 & 1 & 1 & 1 & 0 & & 0 & & 9 & & 9 & & 16 & 0 & & 16 & 0 & & B \\
\hline 5 & 23 & 20 & 15 & 24 & 1 & 1 & 1 & 1 & 0 & & 0 & & 10 & & 14 & & 16 & 0 & & 16 & 0 & & B \\
\hline 6 & - & - & - & - & 1 & 1 & 1 & 1 & 0 & & 0 & & 10 & & 15 & & 16 & 0 & & 16 & 0 & & B \\
\hline 8 & 41 & 43 & 38 & 44 & 1 & 1 & 1 & 1 & 0 & & 0 & & 8 & & 16 & & 16 & 0 & & 16 & 0 & & B \\
\hline 23 & 65 & 100 & 65 & 100 & 1 & 1 & 3 & 1 & 0 & & "0" & $?$ & 20 & & 16 & & 16 & 0 & & 48 & 0 & & B \\
\hline 29 & 36 & 32 & 30 & 43 & 1 & 1 & 1 & 1 & 0 & & 0 & & 9 & & 16 & & 16 & 0 & & 16 & 0 & & B \\
\hline 30 & 12 & 12 & 16 & 12 & 1 & 1 & 3 & 1 & 0 & & 0 & & 21 & & 16 & & 16 & 0 & & 48 & 0 & & B \\
\hline 42 & 34 & 28 & 36 & 32 & 1 & 1 & 1 & 1 & 0 & & 0 & & 12 & & 16 & & 16 & 0 & & 16 & 0 & & B \\
\hline 48 & 31 & 55 & 25 & 24 & 1 & 1 & 1 & 1 & 0 & & 0 & & 10 & & 9 & & 13 & 0 & & 8 & 0 & & B \\
\hline 11 & 63 & 49 & 57 & 51 & 2 & 1 & 3 & 2 & 0 & & 0 & & 18 & & 32 & & 32 & 0 & & 48 & 0 & & B $\quad E$ \\
\hline 33 & 45 & 31 & 40 & 100 & 1 & 1 & 2 & 1 & 0 & $p$ & 0 & & 15 & & 16 & & 16 & 0 & & 32 & 0 & & B \\
\hline 38 & - & - & - & - & 2 & 2 & 2 & 2 & 0 & & 0 & & 28 & & 28 & & 17 & 0 & & 19 & 0 & & B E \\
\hline 3 & 18 & 28 & 25 & 21 & 2 & 1 & 1 & 1 & 1 & $a$ & 0 & & 16 & & 16 & & 32 & 0 & & 16 & 0 & & $A \quad D$ \\
\hline 19 & 14 & 26 & 28 & 21 & 2 & 1 & 1 & 1 & 2 & $\mathrm{~s}$ & 0 & & 16 & & 10 & & 32 & 0 & & 16 & 0 & & B D \\
\hline 34 & 100 & 100 & 100 & 100 & 1 & 1 & 1 & 1 & 12 & $\mathrm{p}$ & 4 & $\mathrm{~s}$ & 16 & & 16 & & 10 & 0 & & 6 & 0 & & B DE \\
\hline 28 & 9 & 15 & 5 & 13 & 1 & 1 & 1 & 1 & 0 & & 0 & & 0 & a & 12 & & 15 & 0 & & 14 & 0 & & C \\
\hline 46 & 20 & 34 & 23 & 24 & 2 & 2 & 1 & 2 & 7 & $\mathrm{~s}$ & 0 & & 6 & & 2 & $\mathrm{~s}$ & 26 & 5 & $\mathrm{~s}$ & 16 & 5 & $\mathrm{~s}$ & $C D$ \\
\hline 51 & 65 & 61 & 72 & 56 & 2 & 2 & 2 & 2 & 0 & & 0 & & 5 & $\mathrm{~s}$ & 19 & & 31 & 1 & $\mathrm{~s}$ & 22 & 1 & $\mathrm{~s}$ & $C D E$ \\
\hline 35 & 77 & 76 & 78 & 79 & 3 & 1 & 1 & 3 & 0 & & 0 & & 0 & a & 9 & $p$ & $12 p$ & 0 & & 16 & 0 & & C E \\
\hline 40 & - & - & - & - & 3 & 1 & 3 & 3 & 0 & & 0 & & 10 & $p$ & 28 & & 48 & 0 & & 28 & 0 & & C E \\
\hline 45 & 10 & 6 & 16 & 5 & 2 & 2 & 2 & 3 & 0 & & 0 & & 5 & $\mathrm{~s}$ & 23 & & 31 & 0 & & 25 & 0 & & $C \quad E$ \\
\hline 43 & 30 & 47 & 39 & 36 & 1 & 1 & 1 & 1 & 9 & $p$ & 6 & $p$ & 16 & & 16 & & 16 & 16 & $p$ & 16 & 0 & & $\mathrm{D}$ \\
\hline 22 & 7 & 5 & 7 & 6 & 3 & 3 & 3 & 3 & 4 & $\mathrm{~s}$ & 44 & $\mathrm{p}$ & 33 & & 27 & & 48 & 0 & & 34 & 0 & & DE \\
\hline 47 & 39 & 26 & 32 & 37 & 3 & 3 & 3 & 3 & 3 & - & 1 & $a$ & 7 & $\mathrm{~s}$ & 18 & & 43 & 0 & & 33 & 0 & & $D E$ \\
\hline
\end{tabular}




\section{Annex 9 Results: PCR ruminant}

\begin{tabular}{|c|c|c|c|c|c|c|c|c|}
\hline \multirow[t]{2}{*}{ lab nr } & \multicolumn{4}{|l|}{ sample } & \multicolumn{4}{|c|}{ ruminant } \\
\hline & A & C & D & & A & B & C & D \\
\hline 3 & 96 & 237 & 188 & 134 & & & present & present \\
\hline 10 & 241 & 97 & 143 & 129 & & & present & present \\
\hline 14 & 116 & 87 & 138 & 234 & present & present & present & present \\
\hline 16 & 191 & 127 & 243 & 69 & & & present & present \\
\hline 19 & 251 & 42 & 88 & 204 & present & present & present & present \\
\hline 21 & 186 & 107 & 133 & 259 & & & present & present \\
\hline 22 & 101 & 152 & 13 & 39 & & & present & present \\
\hline 23 & 71 & 117 & 263 & 239 & absent & absent & present & present \\
\hline 24 & 151 & 182 & 168 & 159 & present & present & present & present \\
\hline 25 & 236 & 207 & 193 & 84 & & & present & present \\
\hline 27 & 41 & 247 & 53 & 94 & present & & present & present \\
\hline 31 & 31 & 177 & 183 & 149 & & & present & present \\
\hline 33 & 36 & 257 & 73 & 264 & present & & present & present \\
\hline 37 & 106 & 202 & 123 & 34 & & & present & present \\
\hline 43 & 61 & 187 & 43 & 9 & present & present & present & present \\
\hline 44 & 156 & 197 & 268 & 174 & present & present & present & present \\
\hline 47 & 206 & 147 & 218 & 124 & present & present & present & present \\
\hline 48 & 131 & 172 & 48 & 249 & present & present & present & present \\
\hline 49 & 91 & 102 & 153 & 14 & & & present & present \\
\hline 52 & 0 & 47 & 28 & 154 & & present & present & present \\
\hline
\end{tabular}

\begin{tabular}{|c|c|c|c|c|c|c|c|c|c|}
\hline \multirow[t]{2}{*}{ lab } & \multirow{2}{*}{$\begin{array}{l}\text { Cut-off } \\
\text { Ct }\end{array}$} & \multirow{2}{*}{$\begin{array}{l}\text { Sample A } \\
\text { Ct }\end{array}$} & \multirow[b]{2}{*}{$\Delta \mathrm{Ct}$} & \multicolumn{2}{|l|}{ Sample B } & \multicolumn{2}{|l|}{ Sample C } & \multicolumn{2}{|l|}{ Sample D } \\
\hline & & & & Ct & $\Delta \mathrm{Ct}$ & Ct & $\Delta \mathrm{Ct}$ & Ct & $\Delta \mathrm{Ct}$ \\
\hline 3 & 32 & & & & & $27.70-29.06$ & 3.62 & $8.92-23.78$ & 15.65 \\
\hline 3 & 32 & & & & & $20.83-20.90$ & 11.14 & $24.22-24.47$ & 7.66 \\
\hline 3 & 32 & & & & & $23.28-23.90$ & 8.41 & $26.78-27.08$ & 5.07 \\
\hline 14 & 34.84 & $29.88-30.52$ & 4.64 & 29.49-29.58 & 5.31 & $23.24-24.80$ & 10.82 & $24.58-25.30$ & 9.90 \\
\hline 16 & 35.72 & 29.98-32.06 & 4.70 & $29.71-30.25$ & 5.74 & $25.55-25.86$ & 10.02 & $25.64-25.70$ & 10.05 \\
\hline 19 & 36.57 & $30.61-30.87$ & 5.83 & $29.99-30.77$ & 6.19 & $26.42-26.72$ & 10.00 & $27.41-27.80$ & 8.97 \\
\hline 21 & 35.43 & & & & & 28.93 & 6.50 & 28.00 & 7.43 \\
\hline 23 & 34.52 & $37.15-37.48$ & -2.79 & $35.14-35.69$ & -0.89 & $28.58-30.00$ & 5.23 & $27.23-27.64$ & 7.09 \\
\hline 24 & 35.29 & $28.18-28.38$ & 7.01 & $28.76-29.57$ & 6.13 & $22.11-24.90$ & 11.79 & $24.00-25.04$ & 10.77 \\
\hline 25 & 32.49 & & & & & $22-23$ & 9.99 & $22-23$ & 9.99 \\
\hline 27 & 31.91 & 27.92 & 4.60 & & & 21.80 & 10.11 & 24.47 & 7.44 \\
\hline 31 & 37.2 & & & & & $24.90-26.20$ & 11.65 & $24.40-25.80$ & 12.10 \\
\hline 33 & 36.9 & 30.16 & 6.74 & & & 25.41 & 11.49 & 26.68 & 10.22 \\
\hline 37 & 36.64 & & & & & $28.32-29.85$ & 7.56 & $28.59-32.28$ & 6.21 \\
\hline 44 & 35.17 & $31.28-31.45$ & 3.81 & $31.69-32.00$ & 3.33 & $26.84-28.37$ & 7.57 & $24.03-27.48$ & 9.42 \\
\hline 48 & 33.78 & 29.01 & 4.77 & 28.19 & 5.59 & 23.84 & 9.94 & 20.76 & 13.02 \\
\hline 49 & 35.87 & & & & & 28.26 & 7.61 & 29.86 & 6.01 \\
\hline
\end{tabular}


RIKILT Wageningen University \& Research P.O. Box 230

6700 AE Wageningen

The Netherlands

$\mathrm{T}+31(0) 317480256$

www.wur.eu/rikilt

RIKILT report 2018.008
The mission of Wageningen University \& Research is "To explore the potential of nature to improve the quality of life". Under the banner Wageningen University \& Research, Wageningen University and the specialised research institutes of the Wageningen Research Foundation have joined forces in contributing to finding solutions to important questions in the domain of healthy food and living environment. With its roughly 30 branches, 5,000 employees and 10,000 students, Wageningen University \& Research is one of the leading organisations in its domain. The unique Wageningen approach lies in its integrated approach to issues and the collaboration between different disciplines.

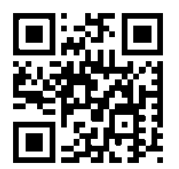





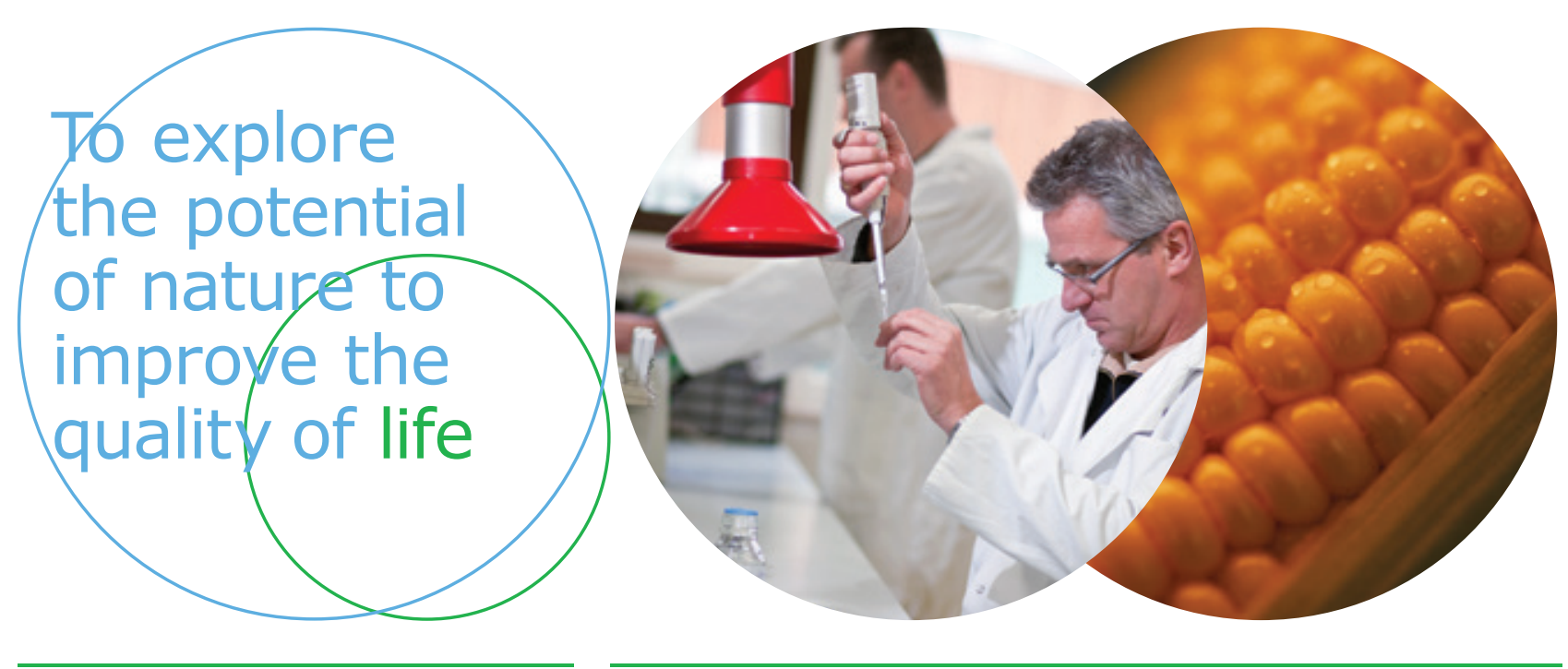

RIKILT Wageningen University \& Research P.O. Box 230

6700 AE Wageningen

The Netherlands

T +31 (0)317480256

www.wur.eu/rikilt

Report 2018.008
The mission of Wageningen University \& Research is "To explore the potential of nature to improve the quality of life". Under the banner Wageningen University \& Research, Wageningen University and the specialised research institutes of the Wageningen Research Foundation have joined forces in contributing to inding solutions to important questions in the domain of healthy food and living environment. With its roughly 30 branches, 5,000 employees and 10,000 students, Wageningen University \& Research is one of the leading organisations in its domain. The unique Wageningen approach lies in its integrated approach to issues and the collaboration between different disciplines. 